\title{
Venir de (+ infinitive)
}

\section{An immediate anteriority marker in French*}

\author{
Jacques Bres \& Emmanuelle Labeau \\ University of Montpellier / Aston University
}

This paper deals with the grammaticalisation of venir into an aspectual auxiliary of immediate anteriority, against the traditional approach (Gougenheim 1971 [1929]) according to which venir de + INF, would express recent past and so would be a temporal auxiliary. On the basis of the (revised) Reichenbachian model, it shows that venir de + INF bears upon the relationship between $\mathrm{R}$ and $\mathrm{E}$ (aspect) and not on the relationship between $\mathrm{R}$ and $\mathrm{S}$ (time). This analysis explains why venir, in this periphrasis, is defective (i.e., why venir cannot be conjugated in the passé simple or in any compound tense).

Keywords: venir de + INF; grammaticalisation of movement verbs; recent past; immediate anteriority; aspectual auxiliary of anteriority; defective conjugation

\section{Introduction}

In many languages, itive and ventive ${ }^{1}$ verb forms (Eng.: go/come, Fr.: aller/venir, Sp.: ir/venir) grammaticalise into temporal, aspectual and modal auxiliaries (e.g., Lamiroy 1983, Hagège 1993, Bybee et al. 1994, Dahl 2000, Heine \& Kuteva 2002, Bourdin 2008, and for French: e.g., Gougenheim 1971 [1929], Bres \& Labeau 2013). COME-periphrases are used for instance to express ANTERIORITY in various languages $^{2}$ and, most specifically, IMMEDIATE ANTERIORITY in French.

\footnotetext{
* We are very grateful to the editor and anonymous reviewers whose insightful comments have helped us to improve our work.

1. Andative/venitive (Bybee et al. 1994, Dahl 2000, Heine \& Kuteva 2002) are also found in literature. We will follow for instance Hagège's (1993:103) choice of itive (Latin ire, supine itum) and ventive (Latin venire, supine ventum).

2. "Among the movement verbs that develop into anterior grams, the most common seem to be 'come' and 'come from"' (Bybee et al. 1994:56).
}

Diachronica 32:4 (2015), 530-570. DOI 10.1075/dia.32.4.03bre ISSN 0176-4225 / E-ISSN 1569-9714 @ John Benjamins Publishing Company 
This paper will focus on venir de + INF in French. That periphrasis has been the subject of much attention (e.g., Gougenheim 1971 [1929], Damourette \& Pichon 1970 [1911-1936], Flydal 1943, Dominicy 1983, Vetters 1989, 2010, Bourdin 1999, 2005, Havu 2005, De Mulder 2010). The present paper complements those works and offers a different analysis of the venir de + INF structure:

i. The grammaticalisation of the venir verb into an auxiliary, while assumed by Vetters $(1989,2010)$ and De Mulder $(2010)$, is not precisely described by them. Our paper, while not bringing anything new on the grammaticalisation phenomenon in itself, describes more precisely the diachronic evolution of the venir verb into a venir auxiliary, and how it has on this path become an ANTERIOR and not a PERFECTIVE. ${ }^{3}$

ii. Damourette \& Pichon 1970 [1911-1936], Flydal 1943, Dominicy 1983, Bourdin 1999, 2005, Havu 2005, De Mulder 2010, Vetters 2010, in different ways, support the traditional approach (Gougenheim 1971 [1929] ) according to which venir de + INF, would express RECENT PAST and so would be a TEMPORAL auxiliary. Here, we analyze it as an ASPECTUAL auxiliary of IMMEDIATE ANTERIORITY. On the basis of the (revised) Reichenbachian model, with the three constructs: $E$ (= event point), $S$ (= speech point) and $R$ (= reference point) ((1947) 1966), we show that venir de + INF bears upon the relationship between $\mathrm{R}$ and $\mathrm{E}$ (that is to say ASPECT) and not on the relationship between $\mathrm{R}$ and $\mathrm{S}$ (that is to say TIME). That analysis allows a solid explanation of a fact that - even though it had been mentioned by all those scholars - had remained unexplained: why venir, in this periphrasis, is defective (i.e., why venir cannot be conjugated in the passé simple or in any compound tense).

We first describe the diachronic grammaticalisation path of venir as an aspectual auxiliary of immediate anteriority in the construction venir de + INF (\$1). We then consider whether it has turned into a PERFECTIVE (\$2) before relating venir de + INF with the grams of anteriority, bis-anteriority and immediate ulteriority in French (\$3). We conclude by comparing the French periphrasis with other Romance ways to express immediate anteriority $(\$ 4)$.

3. We use the notions of ANTERIOR and Perfective as defined by Bybee et al.: "Anteriors (or "perfects" as they are often called) ... signal that the situation occurs prior to reference time and is relevant to the situation at reference time" (1994:54). "Perfectives signal that the situation is viewed as bounded temporally" and are used "for narrating sequences of discrete events in which the situation is reported for its own sake, independent of its relevance to other situations" (1994:54). 
For this purpose, we rely on a corpus of 4,600 attested tokens from various sources and genres: Frantext (a database of literary texts from the 16th to the 20th century): 2,250 tokens; Google (contemporary and mostly non-literary written sources): 2,000 tokens; Europress (written press): 250 tokens; sociolinguistic interviews (corpus CFPP 2000), ${ }^{4}$ daily conversation and television programmes: 100 tokens.

\section{Venir de (+ INF): An aspectual auxiliary of immediate anteriority}

Let us consider the following occurrence:

Mon copain vient de rompre et
My boyfriend come-PRES-3SG DE to break up-INF and
jarrive pas à l'accepter
I manage-PRES-1SG not to it accept-INF.
"My boyfriend has just ended our relationship and I can't accept it."

[teemix.aufeminin.com, 2008; accessed 2013/7/7]

Vient de rompre shows the event of rompre not only as ANTERIOR to the moment of reference simultaneous to the moment of speech, but also IMMEDIATELY anterior. Immediacy corresponds to a degree of remoteness that can be measured in days, possibly months according to the meaning of the event (cf. \$2.1). We return to this in $\$ 2.4$. For now, note that the speaker in (1) does not specify the time interval between the event and the moment of speech: vient de (+ INF) indicates that she perceives this interval as short and the event as still relevant at the moment of speech.

Venir de (+ INF) has been in use since the 16th century as an ASPECTUAL AUXILIARY indicating IMMEDIATE ANTERIORITY. We define these below: AUXILIARY (\$2.1), ASPECTUAL (\$2.2), ANTERIORITY (\$2.3), IMMEDIACY (\$2.4).

2.1 Grammaticalisation of the movement verb venir into an AUXILIARY in the venir de + INF construction

Venir in venir de + INF is a prototypical example of the grammaticalisation of a lexical indication of space into a grammatical marker of 'time': the movement verb - here combined with the preposition $d e$ and followed by an infinitive - has

4. The Corpus de Français Parlé Parisien (CFPP 2000) offers sociolinguistic interviews of inhabitants of several Parisian areas with free access: http://cfpp2000.univ-paris3.fr/. 
become an auxiliary of anteriority in accordance with the developmental path from the lexical source 'come' represented below in Bybee et al. (1994: 105) as:

$$
\text { 'COMe' } \rightarrow \text { ANTERIOR } \rightarrow \text { PERFECTIVE/SIMPLE PAST }
$$

Drawing on Gougenheim (1971 [1929]) and Wilmet (1970) for the diachronic data and Heine's (2003) four-stage model for the description of the grammaticalisation process, the following diachronic evolution can be established:

i. Initial stage: In the Middle Ages, venir de + INF, with a [+ human] subject, means that the subject moves towards an (implicit) destination from an origin (the place where the event encoded by the infinitive takes place) introduced by the preposition $d e$, or it means that the subject has reached the destination by moving from that origin:

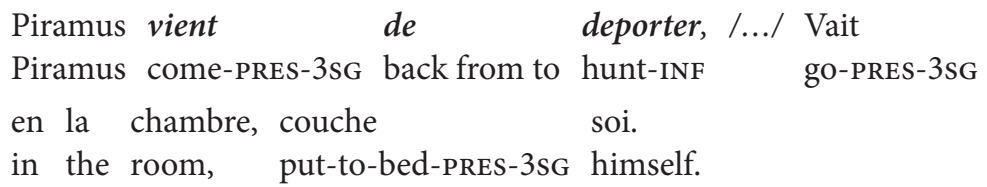

"Piramus comes back from hunting ... goes in the room, and lies down."

[Pyramus, La vie seint Edmund le Rei, late 12th-early 13th century, in Gougenheim (1971 [1929]: 122)]

(3) Chevaliers sui destranges terres / De knight be-PREs-1sG from foreign lands from tournoiier vieng pour conquerre. to-take-part-in-a-tournament-INF come-PRES-1sG to conquer-INF. "I am a knight from foreign lands/I come from taking part in a tournament to conquer."

[Recueil général de fabliaux du XIII ${ }^{\text {ème }}$ et XIV ème, in Gougenheim (1971 [1929]: 122)]

The subject agent is presented as coming back or as de retour après avoir accompli telle ou telle action ["back after completing such and such an action"] (Gougenheim 1971 [1929]: 122): deporter in (2), tournoïier in (3). Revenir carries the same meaning:

(4) Quand il

furent

revenu

de cachier when they-M be-PAST-PERF-3PL come-PP-MPL from hunt-INF ches Grius ... among-the Greeks.

"When they had come back from hunting among the Greeks (...)"

[Robert de Clari, La Conquête de Constantinople, XIII ème, in Gougenheim (1971 [1929])] 
ii. Bridging context: the grammaticalisation of venir does not specifically display the second stage of Heine's (2003) model, where an ambiguous context emerges and allows the inference of a new semantic value. From the initial stage, the movement in space implied by venir $(+d e)$ presupposes that the origin of the movement - the events conveyed by the infinitive - deporter, tournoiier - is anterior to the move: the connotation of anteriority is implied by the spatial move from the very first occurrences. Besides, between the 12th and 15th centuries, this notion - only implied to start with - takes on increasing importance, and venir de (+ INF) in sentences such as (5) can mean anteriority as well as a spatial move:

Quant vient

que le pouvre homme est

venu,

When come-PRES-3SG that the poor man be-PRES-3SG come-PP, qui vient de pourvoier vitaille...

who come-PRES-3SG from provide-INF food-supplies.

"When the poor man arrives, who has just got/come back from getting food supplies."

[Anonymous, Les quinze joies de mariage, 1390]

iii. Switching context: in the 16th century, venir can be used in a context that is incompatible with stage 1 : its subject may be [- animate] such as cinq heures in (6) which prevents an interpretation as a spatial movement and/or it may be followed by a verb that refers to an activity from which the subject agent could not have come back, such as perdre la vie in (7):

(6) Quand je vous ay rencontré, cinq heures

When I you have-PREs-1sG meet-PP, five o'clock

venoient de sonner.

COME-PAST-IMPERF-3PL DE ring-INF

"When I met you, five o'clock had just struck."

[Larivey P., Le Morfondu, 1579]

(7) THESEE: $\quad$ Pren courage, et me dy, sans ton ame troubler,/Quel desastre nouveau vient mon mal redoubler.

MESSAGER: Hippolyte (ô regret !) vient de perdre la vie.

THESEE: Take-IMPER-2sG courage and me say- IMPER-2sG without your soul trouble-INF which disaster new come-PRES-3SG my trouble double-INF

MESSENGER: Hyppolite (oh, regret!) come-PRES-3SG DE lose-INF his life. "THESEE: Take courage and tell me without troubling your soul which new disaster comes to intensify my misfortune.

MESSENGER: Hyppolite (oh, regret!) has just lost his life."

[Garnier R., Hippolyte, 1585] 
The initial constraints on the choice of the subject as well as on the verb have by now been lifted. This process accompanies a semantic shift: the spatial value of movement is overshadowed by a value of immediate anteriority. More precisely, the agent does not move in space anymore, but the CONCEPTUALIZER moves in an "abstract motion" (Langacker 1986:466). Because of the preposition de, the abstract motion of the CONCEPTUALIZER goes towards the origin (the verb in the infinitive) from the destination in a RETROSPECTIVE MOVEMENT that entails the understanding of anteriority.

This semantic change comes with a syntactic reanalysis of [venir $+d e+\mathrm{INF}]$ into [(venir de $)+\mathrm{INF}]$ by which, venir de becomes - by abstraction - merely an auxiliary. This imposes a constraint on word order: venir must necessarily precede the infinitive while it could be postponed in the spatial use as in (3): De tournoiier vieng pour conquerre. The emergence - and spread of that new structure - is independent of the discursive genre: it can be found in comedies as well as in tragedies, in poetry as well as in direct reported speech.

Yet, it is still possible in the 16th century to use venir as a motion verb (with, of course, implied anteriority):

(8) Guillot ..., caché derriere un buisson, au soir, Guillot (...) hide-PP-MSG behind a bush in-the evening, attend Marion qui vient de querir ses wait-PRES-3SG Marion who come-PRES-3SG from seek-INF her vaches, doubteux si elle luy refusera ce dequoy elle cows, doubtful if she him refuse-Fs-3sG what by-what she a esté par luy souventesfois importunee. have-PRES-3sG be-PP by him many-times bother-PP-FSG. "Guillot ... hidden behind a bush, in the evening waits for Marion who comes back from fetching (come-PREs-3sG from seek-INF) her cows, wondering whether she will refuse him what he has many times bothered her about."

[DU FAIL Noël, Les Propos rustiques de Maistre Leon Ladulfi champenois, 1547]

In (8), venir de retains a full spatial meaning: it can easily be replaced by revenir de: "Marion qui vient de querir ses vaches" $\approx$ Marion qui revient de querir ses vaches. The human agent Marion comes back from performing an action, i.e., fetching her cows.

iv. Conventionalisation: in the 17th century, venir de is only ever used as an auxiliary: 
(9) Cratesiclea. Est-il donc mort mon fils?

Cratesiclea. be-PREs-3sg he thus dead my son?

Pheax. Il vient de rendre l'ame.

Pheax. he come-PRES-3SG DE give-INF back the soul.

"Cratesiclea. Is my son thus dead?

Pheax. He has just expired."

[Montchrestien A., Les Lacènes, 1604]

This example cannot mean a physical move away from an event. ${ }^{5}$ This meaning is from this point onwards conveyed by revenir de:

(10) Il revient de chercher d'un autre coté, et $\mathrm{He}$ come-PRES-3sg back from seek-INF of another side and rapporte les deux pièces de l'épée rompue bring-back-PRES-3sG the two pieces of the sword break-PP-FSG de Rosidor.

of Rosidor.

"He comes back from seeking elsewhere and brings back the two pieces of Rosidor's broken sword."

[Corneille P., Clitandre ou l'Innocence délivrée, 1632]

New contexts emerge from the 17th century onward and confirm the grammaticalisation of venir into an auxiliary. Consider two. On the one hand, the impersonal construction completely deprives venir of an agent (11), inasmuch as it only has as its grammatical subject the impersonal pronoun $i l$ :
Il vient
de me souvenir
que certains
It come-PRES-3SG DE me remember-INF that some demy-çavans ont remarqué que les personnages de half-learned-people have-PRES-3PL notice-PP that the characters of ma Tragi-comedie y parlent des Dieux en pluriel. my tragi-comedy there speak-PRES-3PL of-the Gods in plural.

"I just happen to remember that some half-educated people have noticed that the characters of my tragi-comedy speak of Gods in the plural within it."

[Scudéry G. de, Ligdamon et Lidias ou la Ressemblance, 1631]

On the other hand, the 'proof by anachrony principle' (Hagège 1993:200-202) refers to the possibility of applying the grammaticalised construction to the lexical verb, in other words the construction venir de venir:

5. This differs from Spanish, for instance, which does not use venir to express immediate anteriority (cf. yet see $\$ 4$ ) and keeps using that verb in front of an infinitive to convey a meaning of movement: vengo de ver a mi novia ("I come back from visiting my girlfriend/fiancée"). 
(12) Nous sommes en grande apprehension du bruict qui We be-PRES-1PL in great fear of-the noise that vient de venir de la rupture du traicté de come-PRES-3SG DE come-INF of the breaking of-the treaty of la paix.

the peace.

"We are in great fear of the news that has just come of the breaking of the peace treaty."

[Peiresc N., Lettres à M. D'ANDILLY, 1622]

Criticized by purists but accepted as 'familiar' by the dictionary of the French Academy in 1740, vient de venir later enters literature (13) and can even be found in contemporary internet chats (14):

(13) Un juge, un commissaire, un magistrat, je ne sais de A judge, a police officer, a magistrate, I not know-PREs-1sG of quelle espèce, vient de venir. Je lui ai what type come-PRES-3Sg DE come-INF I to-him have-PREs-1sG demandé ma grâce en joignant les deux mains. ask-pp my pardon in joining the two hands.

"A judge, a police officer, a magistrate of whatever type has just come. I have asked him for pardon with clasped hands."

[Hugo V., Le Dernier jour d’un condamné, 1829]

(14) Il était une fois un ado de 13ans qui a voulu It was one time a teen of 13 who have-PREs-3sg want-PP sortir avec une nouvelle, qui venait de venir go-out with a new-FSG who come-PAST-IMPERF-3SG DE come-INF d'un autre établissement public. from another school public.

"Once upon a time, a teenager of 13 wanted to go out with a new girl who had just come from another state school."

[www.jeuxvideo.com/2010, accessed 10/10/2013]

The fact that the sequence of both uses of venir does not prove problematic for users is the clearest sign of the grammaticalisation of venir de as auxiliary.

\subsection{Venir de as an ASPeCtual auxiliary}

Venir de + INF is commonly referred to as 'recent past'. That name, suggested by Gougenheim (1971 [1929]) and adopted e.g., by Vetters (2002), Havu (2005) and 
De Mulder (2010) focuses on the temporal side but obliterates the aspectual side. ${ }^{6}$ While that label is relevant for occurrences such as (1) in which venir is in the present, it does not apply when venir is in the imperfect (15), future (16) or conditional (17), as far as the indicative mood is concerned:

Lautre jour, elle m’a parlé d'un type qu’elle The other day, she me have-PRES-3sG speak-PP of a guy that she venait de rencontrer, à la faculté. Il COMe-PAST-IMPERF-3SG DE meet-INF at the university. He est fascinant, dit-elle. be-PRES-3SG fascinating, say-PRES-3Sg she.

"The other day, she told me about a guy she had just met at university. He is fascinating, she says."

[Perrut D., Patria o muerte, 2009]

(16) On verra Mathieu tout jeune et sûr de lui, il One see-Fs-3sg Mathieu all young and sure of himself, he viendra de plaquer une bonne femme parce qu'il come-FS-3SG DE dump-INF a good woman because he avait peur qu'elle n'en voulût à have-PAST-IMPERF-3sG fear that she NEG EN want-SUBJ-IMP-3SG to sa liberté.

his freedom.

"Mathieu will be seen very young and self-assured, he will have just dumped a woman because he feared she would try to deprive him of his freedom."

[Sartre J.-P., Lettres au Castor, 1940-1963]

(17) Elle s'est habituée à dormir seule. Mais elle She herself be-PRES-3sg use-PP-FSg to sleep alone. But she aurait bien aimé dormir à Roscoff avec un have-COND-3sG well like-PP sleep-INF in Roscoff with an inconnu, le coeur en bandoulière, que sa femme unknown-m, the heart in shoulder-strap, that his wife viendrait de quitter pour un ouvrier arabe. Come-COND-PS3 DE leave-INF for a manual-worker Arab. "She had become used to sleeping alone. Yet she would have liked to sleep in Roscoff with a stranger with his heart on his sleeve whom his wife would have just left for an Arab manual worker."

[Lange M., Les Cabines de bain, 1982]

6. The construction has also been referred to as expressing récence (introduced by Flydal 1943, see also Bourdin 1999, 2005, and Bres \& Labeau 2012), or précédence for Damourette \& Pichon (1911-1936), who thereby avoid our criticism of the designation 'passé récent'. 
A purely temporal approach to venir de + INF proves even more irrelevant for atemporal moods (Guillaume 1971 [1929]) such as the subjunctive (e.g., 18 and 19), participle (e.g., 20), and infinitive (e.g., 21):

(18) Bien qu'elle vienne de fêter ses soixante-dix

Even that she come-SUBJ-PRES-3SG DE celebrate-INF her sixty-ten

ans -et pas une ride!-, la reine de la soul nest years -and not one wrinkle- the queen of the soul NEG be-PRES-3sG pas prête à céder sa couronne. NEG ready to give-up-INF her crown.

"Although she has just celebrated her 70th birthday - and still no wrinkles! - the queen of soul is not ready to give up her crown."

[https://fr.news.yahoo.com/aretha-franklin/, accessed 2014/08/05]

(19) C'est que je venais de l'entendre rire. Et This be-PREs-3Sg that I come-IMP-1SG DE him hear-INF. And ce rire évoquait aussitôt les roses this laugh evoke-PAST-IMPERF-3sg straightaway the pink carnations, les parois parfumées contre lesquelles il complexions, the wall-partitions perfumed against which he semblait qu'il vint de seem-PAST-IMPERF-3SG that he Come-SUBJ-IMP-3SG DE

se frotter

himself rub-INF.

"I just had heard him laugh. And that laugh immediately evoked the pink complexions, the perfumed wall partitions against which it seemed he had just rubbed himself."

[Proust, M. À la recherche du temps perdu, 1913]

(20) Si tous les hommes venant de se faire plaquer If all the men come-PPRES DE themselves make-INF dump-INF et ayant un manque sexuel finissaient aux and have-PPRES a lack sexual end-PAST-IMPERF-3PL on-the abords des routes, il y aurait du neighbourhoods of-the roads, it there have-ConD-Ps3 of-the monde non? crowd no "If all the men having just been dumped and feeling a sexual frustration ended up on the street, there would be a crowd, wouldn't there?"

[forum.psychologies.com '... 'Paroles d'hommes, 7th Nov. 2007, accessed 2014/8/5] 
(21) Il partait

He leave-PAST-IMPERF in direction of the castle without have-INF rien dit, mais quelque chose semblait venir de nothing say-PP, but some thing seem-PAST-IMPERF (Come-INF DE mourir en lui. die-INF) in him.

"He was going away towards the castle without having said anything, but something seemed to have just died in him."

[mutinlutin.forum-actif.net/t249p15-cauchemar, accessed on 2014/8/5]

If venir can be used in all moods and in various tenses, it is because it is an ASPECTUAL auxiliary, which we now demonstrate using the following arguments. GRAMMATICAL aspect refers to the range of ways by which a language can represent the INTERNAL TIME (Comrie 1976) of an event in the various phases of its development. It is distinguished from LEXICAL ASPECT that relates to the type of event ('state', 'activity', 'accomplishment' and 'achievement' according to Vendler (1967)).

An event can be comprehended according to three phases (e.g., Dik 1989, Tournadre 2004, Gosselin 2011): pre-process, process (further split into initial, median and final phases) and post-process, as illustrated below:

$\begin{array}{llll}\text { Phases } & \text { pre-process } & \text { process } & \text { post-process } \\ & & & \\ & \text { initial median } & \text { final }\end{array}$

Figure 1. Phases of an event

French indicates grammatical aspect in two ways:

i. For the process phase: as verbal affixes, in so-called SIMPLE TENSES. For the indicative: présent, passé simple, ${ }^{7}$ imparfait, futur simple, conditionnel présent. The passé simple/imparfait dichotomy allows a distinction between a PERFECTIVE representation of the process phase (il plut - it rain-PAST-PERF-3SG) and an IMPERFECTIVE representation (il pleuvait - it rain-PAST-IMPERF-3SG). The present, future and conditional tenses are underspecified and do not convey that aspectual distinction (Barceló \& Bres 2006). ${ }^{8}$

7. The uses of passé simple have substantially shrunk over time (cf. infra, \$4.1.). In contemporary usage, it tends to be restricted to written language in historical enunciation (Benveniste 1966 [1959]), in texts in the 3rd person that are cut from the moment of speech.

8. Linguists do not agree on this. Some analyse the present as offering, like the imperfect, an imperfective presentation. This has no impact on the explanation developed under $\$ 2.3$ of why the construction is defective. 
ii. For the post-process phase: as auxiliaries that carry the same affixes as the verb in the process stage, which means they are conjugated and followed by a past participle or infinitive. They include (a) the auxiliaries être and avoir with the past participle forming the COMPOUND TENSES (for the indicative mood: passé composé, passé antérieur, plus-que-parfait, futur antérieur, conditionnel passé); ${ }^{9}$ (b) the venir de, ne faire que de, sortir de auxiliaries (+ INF). ${ }^{10}$

Venir de belongs to the post-process phase: whatever its mood or tense, it posits the reference interval (infra $\$ 2.3$ ) at close distance beyond the final border of the process phase. We now formally describe and more precisely define this meaning of immediate anteriority.

\subsection{Venir de as an aspectual auxiliary of ANTERIORITY}

Reichenbach (1966 [1947]) describes English verbs by means of three constructs: $E$ (= event point), $S$ (= speech point) and $R$ (= reference point). $E$ and $\mathrm{R}$ on the one hand, and $\mathrm{R}$ and $\mathrm{S}$ on the other hand, can be articulated by two ordering relations of anteriority (-) and simultaneity (,). The relation between E/R is of an aspectual nature; that between $\mathrm{R} / \mathrm{S}$ is temporal. To provide a more precise description of the venir de + INF construction, we supplement this analysis in four ways:

i. The anteriority relation between $\mathrm{E}$ and $\mathrm{R}$, contrary to what is implied by Reichenbach's model, can be not only QUaLITATIVE but also QUANTITATIVE (Vetters 2002:115-118), and indicate various degrees of remoteness (Dahl 1983:111, Comrie 1985:83-101). This applies to French with a relation of close anteriority between $\mathrm{E}$ and $\mathrm{R}$ that we represent by $<$, which allows the distinction between tenses where the post-process phase is indicated by être/ avoir + PP from those where it is indicated by venir de + INF. That is, if we take for instance the distinction between passé composé (22a) and 'passé récent' (22b):

(22a) Il a plu: E-R,S (E is anterior to R, which is simultaneous with $S$ )

(22b) Il vient de pleuvoir: $\mathrm{E}<\mathrm{R}, \mathrm{S}$ ( $\mathrm{E}$ is immediately anterior to $\mathrm{R}$, which is simultaneous with S)

ii. Taking the three constructs $\mathrm{E}, \mathrm{R}$ and $\mathrm{S}$ as points does not allow the representation of the aspectual dimension of the event, since a point cannot be represented under various aspects. Klein (1994) and Gosselin (1996) have

9. This does not take into account surcompound tenses (a eu plu, etc.), cf. infra $\$ 4.1$.

10. The aller, être sur le point de, être en passe de auxiliaries should also be mentioned, for the pre-process phase; and, être en train de, être à for the process phase. 
suggested in distinct theoretical frameworks analysing them as intervals. In their wake, we postulate an interval for $E\left(E_{1}-E_{2}\right)$, for $R\left(R_{1}-R_{2}\right)$ and for $\mathrm{S}\left(\mathrm{S}_{1}-\mathrm{S}_{2}\right)$. That is:

(22b) Il vient de pleuvoir: $\mathrm{E}_{1}-\mathrm{E}_{2}<\mathrm{R}_{1}-\mathrm{R}_{2}, \mathrm{~S}_{1}-\mathrm{S}_{2}$ (the final border $\mathrm{E}_{2}$ of the $\mathrm{E}$ interval is immediately anterior to the $\mathrm{R}$ interval, which is simultaneous with the S interval)

iii. The description in (22b) is not yet satisfactory: it postulates an event interval $E_{1}-E_{2}$ for the verb (pleuvoir), but not for the auxiliary venir, which is only represented as a reference interval. Yet, if venir can be conjugated in different tenses (with restrictions discussed below), this means it can be represented under different viewpoints, in other words, according to a range of relations between reference interval and event interval. ${ }^{11}$ We admit that venir, along with être and avoir, as auxiliaries resulting from the grammaticalisation of processes referring to events, have an event interval (represented by $\varepsilon_{1}-\varepsilon_{2}$ ). This interval $\varepsilon_{1}-\varepsilon_{2}$ of venir, as we deal with a post-process auxiliary, is close to the $\mathrm{E}_{1}-\mathrm{E}_{2}$ interval of the pleuvoir event, which implies that the initial border $\varepsilon_{1}$ of venir coincides with the final border $\mathrm{E}_{2}$ of the infinitive $\left(\varepsilon_{1}, \mathrm{E}_{2}\right)$. So the intervals of pleuvoir and venir (de) could be represented as follows:

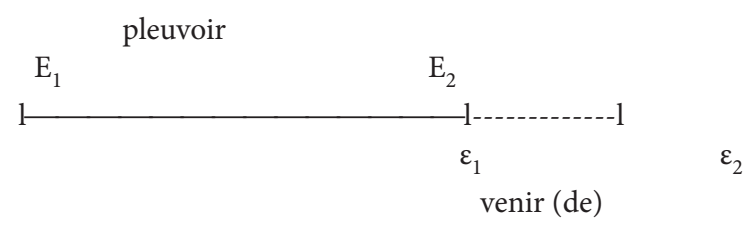

Figure 2. Representation of venir de in our revised Reichenbachian model

iv. To Reichenbach's relations of simultaneity (,) and anteriority (-) we add a relation of INCLUSION $(\subset)$ that allows the distinction between the passé simple (PERFECTIVE representation) and the imparfait (IMPERFECTIVE representation):

(22c) il plut: $E_{1}-E_{2}, R_{1}-R_{2} ; R_{2}-S_{1-}$ (The R interval is simultaneous to that of $E$ and anterior to the interval of $S$ )

(22d) il pleuvait: $R_{1}-R_{2} \subset E_{1}-E_{2} ; R_{2}-S_{1}$ (The $R$ interval is included within that of $E$ and anterior to the interval of $S$ )

11. When, further down the grammaticalization path, the auxiliary turns into an affix - as with the periphrases cantare habet/cantare habebat that became synthetic future and conditional chantera /chanterait in Romance - it no longer has access to a process interval: its phonological reduction is coupled with semantic whittling away. 
This reworking of Reichenbach's model including the introduction of relation of proximal anteriority $(<)$ and inclusion $(\subset)$ between $\mathrm{E}$ and $\mathrm{R}$, the replacement of the $\mathrm{E}, \mathrm{R}, \mathrm{S}$ constructs by intervals and the addition of an interval $\varepsilon_{1}-\varepsilon_{2}$ for venir - allows the resolution of an enigma that, as far as we are aware, has not been elucidated until now, namely the defective nature of venir as a marker of immediate anteriority that cannot be conjugated in the passé simple (as far as the indicative mood is concerned) (22e) nor in any compound tenses (22f):

(22e) ${ }^{*}$ Il vint de pleuvoir

"It COMe-PAST-PERF-3SG DE rain-INF."

${ }^{*}$ Il est venu de pleuvoir, ${ }^{*}$ etre venu de pleuvoir, etc.

"It is-PRES-3SG come-PP-MSG DE rain-INF."

Il vient de pleuvoir presupposes a small temporal gap between the reference interval, here conflated with the speech interval and the time when the rain fell (event interval). We hypothesize that some tenses, thanks to their aspect or in other words the relation between the reference interval and the event interval, allow the expression of this small anterior gap, while other tenses forbid it. In the present case, this shows in the fact that venir can be used in the imparfait but not in the passé simple nor any compound tense. The following examples will illustrate this point.

(22g) Il venait de pleuvoir: $\mathrm{R}_{1}-\mathrm{R}_{2} \subset \varepsilon_{1}-\varepsilon_{2} ; \mathrm{E}_{2}<\mathrm{R}_{1} ; \mathrm{R}_{2}-\mathrm{S}_{1}$ (the reference interval $\mathrm{R}_{1}-\mathrm{R}_{2}$ is included within the process interval venir $\varepsilon_{1}-\varepsilon_{2}$; the final border $\mathrm{E}_{2}$ of pleuvoir is immediately anterior to the initial border of the reference interval $R_{1}$; the final border of the reference interval $R_{2}$ is anterior to the initial border $S_{1}$ of the speech interval)

Il venait de pleuvoir: thanks to its imperfective aspect, the imparfait includes the reference interval $R_{1}-R_{2}$ within the process interval $\varepsilon_{1}-\varepsilon_{2}$ in such a way that $\varepsilon_{1}$ is closely anterior to $\mathrm{R}_{1}\left(\varepsilon_{1}<\mathrm{R}_{1}\right)$, which, given the proximity between the intervals of pleuvoir and venir, leaves a gap between $\mathrm{E}_{2}$ and $\mathrm{R}_{1}\left(\mathrm{E}_{2}<\mathrm{R}_{1}\right)$ that complies with the requirements of a representation of immediate anteriority.

This can be represented as follows:

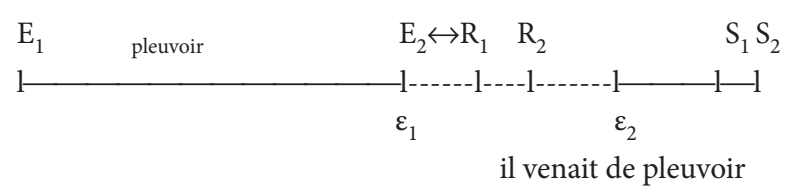

Figure 3. Representation of venait de + INF. in our revised Reichenbachian model

${ }^{\star}$ Il vint de pleuvoir: the perfective aspect of the passé simple results from the coincidence of the reference interval with the event interval. Conjugating venir in the 
passé simple would make the reference interval $\mathrm{R}_{1}-\mathrm{R}_{2}$ and the event interval $\varepsilon_{1}-\varepsilon_{2}$, coincide, which, given the proximity of the event intervals for pleuvoir and venir (de), would amount to making the initial border R1 of the reference interval coincide with the final border $\mathrm{E}_{2}$ of pleuvoir, and would leave no space between $\mathrm{E}_{2}$ and $\mathrm{R}_{1}$, as required for representing proximal anteriority:

(22h) ${ }^{*}$ Il vint de pleuvoir: $\mathrm{R}_{1}-\mathrm{R}_{2}, \varepsilon_{1}-\varepsilon_{2} ; \mathrm{R}_{1}, \mathrm{E}_{2} ; \mathrm{R}_{2}-\mathrm{S}_{1}$ (the reference interval $R_{1}-R_{2}$ would be simultaneous to the event interval venir $\varepsilon_{1}-\varepsilon_{2}$; the initial border $\mathrm{R}_{1}$ would be simultaneous to the final border $\mathrm{E}_{2}$ of pleuvoir, and the final border $R_{2}$ would be anterior to the initial $S_{1}$ of the speech interval)

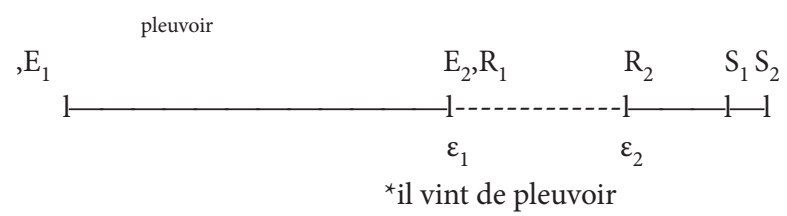

Figure 4. Representation of vint de + INF in our revised Reichenbachian model

The restrictions on compound forms can be explained in a similar way. Let us just consider the participle venant de pleuvoir: like the imparfait, the present participle carries an imperfective aspect so it can be applied to venir for the same reasons that allowed the imparfait. The only difference comes from the fact that the participle is an atemporal mood, which implies that the speech interval is not needed for its description. We thus have:

(22i) Venant de pleuvoir: $\mathrm{R}_{1}-\mathrm{R}_{2} \subset \varepsilon_{1}-\varepsilon_{2} ; \mathrm{E}_{2}<\mathrm{R}_{1}$ (the reference interval $\mathrm{R}_{1}-\mathrm{R}_{2}$ is included within the event interval of venir $\varepsilon_{1}-\varepsilon_{2}$; the final border $\mathrm{E}_{2}$ of pleuvoir is immediately anterior to the initial border of the reference interval $\mathrm{R}_{1}$ )

*Étant venu de pleuvoir: the compound form bears upon the post-process phase and shows the reference interval $R_{1}-R_{2}$ after the final border of the event interval. Conjugating the compound form of the present participle (étant venu) would place the interval $R_{1}-R_{2}$ beyond the final border $\varepsilon_{2}$, and therefore would move it away from the final border $\mathrm{E}_{2}$. The gap indicating anteriority between $E_{2}$ and $R_{1}$ would be expanded, which goes against the meaning of proximal anteriority:

(22j) *étant venu de pleuvoir: $\varepsilon_{2}-\mathrm{R}_{1} ; \mathrm{E}_{2}-\mathrm{R}_{1}$ (the process interval venir $\varepsilon_{1}-\varepsilon_{2}$ would be anterior to the reference interval $R_{1}-R_{2}$, which would increase the gap between the final border $\mathrm{E}_{2}$ of pleuvoir and the reference interval) 


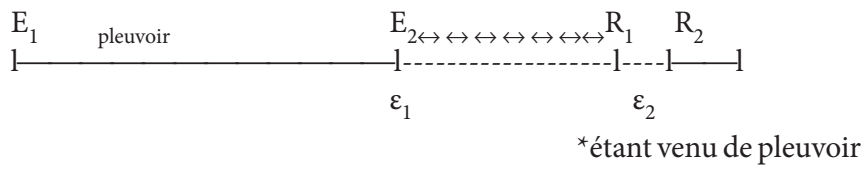

Figure 5. Representation of étant venu de + INF in our revised Reichenbachian model

The description of venir de + INF periphrasis outlined above is supported by the tenses in which venir is defective: the aspectual relation between the reference interval and the event interval $\varepsilon_{1}-\varepsilon_{2}$ of venir in its relation with the event interval for the infinitive permits the use of some tenses but not of others. Venir (de) can be conjugated in all the simple tenses of all moods (except the passé simple in the indicative). Most occurrences are in the present and the imperfect of the indicative mood. Indeed, out of 4,600 authentic tokens in our corpora, $67 \%$ are in the present and $26 \%$ in the imperfect of the indicative.

Venir de acts as an auxiliary of anteriority for the four aspectual classes suggested by Vendler (1967), but they are not evenly distributed. The percentages below were calculated on the basis of the first 100 occurrences of venir de + INF, in all tenses, for each of the four centuries (17th, 18th, 19th and 20th) covered in Frantext:

Table 1. Distribution of aspectual classes

\begin{tabular}{cccc}
\hline States & Activities & Accomplishments & Achievements \\
\hline $0.5 \%$ & $6.5 \%$ & $17 \%$ & $76 \%$ \\
\hline
\end{tabular}

Venir de, as an auxiliary of the post-process phase, presupposes that the event is over; therefore, it combines ideally with telic events (achievements, accomplishments) that imply an intrinsic endpoint, less so with atelic events and not at all with unbounded states. There are few occurrences of bounded states (non-permanent) such as être malade "to be sick" (23), but none of unbounded states (permanent), p. ex. être la fille de "to be the daughter of" (24):

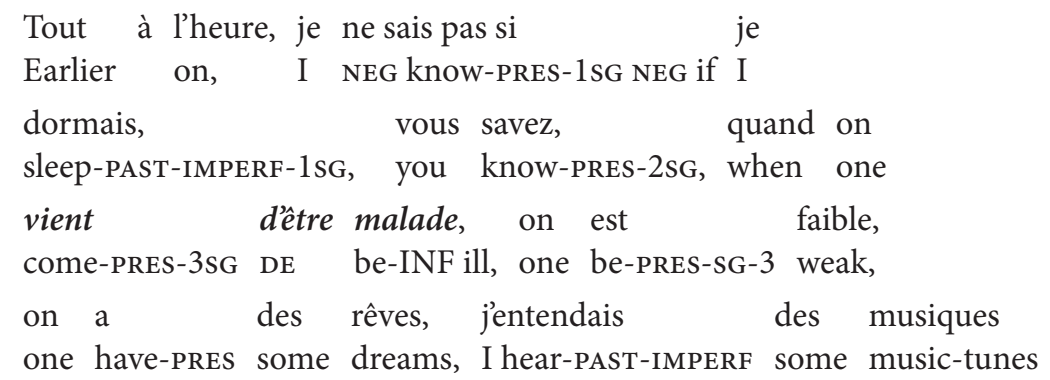


dans l'air.

in the air.

"Earlier on, I don't know whether I slept, you know when one has just been ill, one is weak, one has dreams, I was hearing melodies in the air."

[Hugo V., Mille francs de récompense, 1866]

${ }^{*}$ Mary venait d'être la fille
Mary come-PAST-IMPERF-3SG DE be-INF the daughter
du prince.
of-the prince.
"`Mary had just been (come-IMP-3sG from be-INF) the daughter of the
prince."

It is difficult or even impossible to represent être la fille $d u$ roi as immediately anterior to another event inasmuch as that state does not have an intrinsic endpoint.

\subsection{Venir de as an immediate anterior}

How can we explain that venir de conveys a meaning not only of anteriority, but of immediate anteriority? When used as a movement verb, venir can combine with a place of origin that is far away from the place of destination: mon copain vient de lautre bout du monde ["my boyfriend comes from the other side of the world"]. Why then, when venir is an anteriority auxiliary, the time gap between the origin expressed by the infinitive and the reference interval is minimal? For instance in (1a), the time gap between rompre and the reference interval $\mathrm{R}$ that coincides with the speech interval can be defined by adverbials such as ce matin [this morning], la semaine dernière [last week], le mois dernier [last month] (cf. infra \$2). The combination is less natural with il y a six mois [six months ago], and becomes problematic with il y a 2 ans [2 years ago]:

(1b) Mon copain vient de rompre ce matin/la semaine dernière/le mois dernier/?il y a six mois / *il y a 2 ans ${ }^{12}$

Our tentative hypothesis is this: French resorts to compound forms (avoirlêtre + participe passé) to indicate that the event is anterior to a moment of reference (E-R), without specifying the distance between both intervals: for instance in (1a), if "mon copain vient de rompre" is replaced by "mon copain a rompu", rompre is presented as anterior, but without any specification of the distance from the speech interval. Indicating with another auxiliary (venir de) - in other words a

12. The event type as well as its meaning contribute to the variations in immediacy. Vetters (2002:120) appropriately speaks of proportionnalité. 
grammatical component bearing upon the verb - the anteriority of the event is relevant only if that anteriority is minimal $(\mathrm{E}<\mathrm{R})$. This proximity is not required for spatial distance where venir works as a verb. That hypothesis is supported by two facts: the other Romance languages specify the anteriority of the event as immediate and not remote (see below $\$ 4$ ); Heine \& Kuteva (2002:72-73) give COME FroM as a source of near past, or of perfect in a range of languages. ${ }^{13}$

In $\$ 2$, we explained in turn the four features that make venir de + INF an aspectual auxiliary of immediate anteriority. Hopper \& Traugott (1993: 108) summarize the grammaticalisation cline from full verb to affix this way: full verb $>$ auxiliary $>$ clitic $>$ affix. Vient de + INF is thus at stage 2 (auxiliary). Is an evolution towards stages 3 (clitic) and 4 (affix) possible? The evolution seems unlikely: être and avoir, on which all French compound tenses are built and that have grammaticalized into auxiliaries well before venir, have not gone any further down the cline towards clitics and affixes, unlike what happened for the future and the conditional (see Note 11) in which the periphrases cantare habet /cantare habebat became synthetic future and conditional chantera/chanterait. Therefore, it seems that French stops on the cline at the auxiliary stage when that auxiliary is placed before the verb, as for venir de + INF, (and indeed of aller + INF in its temporal meaning of immediate ulterior, cf. infra $\$ 3.3$ ), but lets it go further when the auxiliary is placed after the verb as with the future and conditional.

In the next sections, we turn to three questions: why has venir de + INF not come to be used as a perfective as centuries have gone by $(\$ 3)$ ? How is anteriority conveyed without any specification of the degree of remoteness $(\$ 4)$ ? Which solutions have been adopted by the other Romance languages to express immediate anteriority $(\$ 5)$ ?

\section{On the road to perfectivity?}

Recall (Note 3) the difference between anterior and perfective highlighted by Bybee et al. 1994: "Anteriors signal that the situation occurs prior to reference time and is relevant to the situation at reference time" (p. 54). "Perfectives signal that the situation is viewed as bounded temporally" and are used "for narrating sequences of discrete events in which the situation is reported for its own sake, independent of its relevance to other situations". Has venir de + INF increasingly become a perfective since the 17th century, as suggested by Vetters $(1989,2010)$ on the basis of few occurrences? We have measured that hypothesis against 4,000 occurrences from

13. Yet Bybee et al. refer to соме and to соме ғROM only as anterior grams (1994:56). 
our corpus, applying three tests by which a perfective can be distinguished from an anterior: the possibility to be combined with an adverbial, to tolerate a whenquestion, and to be used in narrative progression (Givon 1982).

\subsection{Venir de + INF + temporal adverbial}

Frantext: we collected the occurrences of venir de in the 3rd person singular of the présent and the imparfait (inputs vient/venait de + INF, as they are the most frequent) on the 10 following verbs (or verbal phrases): apprendre "to learn", arriver "to arrive", avoir lieu "to happen", décéder "to decease", épouser "to marry", se marier "to get married", naître "to be born", quitter "to leave", rencontrer "to meet", trouver "to find" - a total of 2,079 oc. - and set apart those followed by a temporal adverbial:

Table 2. Proportion of periphrases followed by a temporal interval in Frantext

\begin{tabular}{lcc}
\hline & Occurrences & Followed by a temporal adverbial \\
\hline vient de + INF & 1127 & 23 \\
venait de + INF & 952 & 26 \\
Total & 2079 & 49 \\
\hline
\end{tabular}

The proportion, in a corpus of around 1,000 occurrences for each tense, is low and comparable for both présent and imparfait: only $2 \%$ of occurrences for vient de+ INF and $2.79 \%$ for venait de + INF are followed by a temporal adverbial.

Diachronically, the 49 occurrences in which vient/venait de + INF are followed by a temporal adverbial and distributed as follows:

Table 3. Occurrences followed by a temporal adverbial by century

\begin{tabular}{lccccr}
\hline & 16th & 17th & 18th & 19th & 20th \\
\hline vient de + INF & 0 & 3 & 2 & 11 & 8 \\
venait de + INF & 0 & 0 & 2 & 13 & 10 \\
Total & 0 & 3 & 4 & 24 & 18 \\
\hline
\end{tabular}

This allows us to draw some observations (provided that our corpus - amounting to $6 \%$ of the 33,400 occurrences of venir de + INF in the Frantext database - is representative): 
i. No occurrence of an adverbial is found in the 16th century;

ii. The sporadic presence of the adverbial, attested since at least the 17 th century, develops somewhat in the 19th century but does not increase in the 20th;

iii. That evolution is accompanied by a wider range of adverbials, the temporal scope of which widens through centuries:

Table 4. Distribution of temporal adverbial types in diachrony

\begin{tabular}{lccccr}
\hline Anteriority & 17th & 18th & 19th & 20th & Total \\
\hline Immediate & 3 & 2 & 6 & 3 & 14 \\
Hodiernal & 0 & 1 & 6 & 7 & 14 \\
Prehodiernal/day & 0 & 1 & 5 & 3 & 9 \\
Prehodiernal/month & 0 & 0 & 1 & 3 & 4 \\
Prehodiernal/year & 0 & 0 & 1 & 1 & 2 \\
Datation & 0 & 0 & 1 & 0 & 1 \\
Anaphoric reference & 0 & 0 & 2 & 1 & 3 \\
Indefinite & 0 & 0 & 2 & 0 & 2 \\
Total & 3 & 4 & 24 & 18 & 49 \\
\hline
\end{tabular}

In the 17th century, only adverbials of immediate past (à l'instant même "right now", tout à l'heure "earlier on") can be found. In the 18th century, hodiernal (la nuit même ["that very night") and prehodiernal (anteriority counted in days: il y a quelques jours "a few days ago") appear, although they are isolated attempts. In the 19th century, adverbials indicating degrees of remoteness in months (depuis deux mois "for the last two months"), even years (deux ans auparavant "two years before") appear, as well as other types of temporal information: dates (en 1677), anaphorical reference (au sortir du couvent "upon leaving the convent") or undefined reference (dernièrement "lately"). The diversification is confirmed, but not increased in the 20th century.

iv. Contrary to received wisdom, the construction is not (completely) resistant to depuis $x$ temps "since $\mathrm{x}$ time" that appears in 9 oc./49, all from the 19th and 20th centuries, that introduce degrees of remoteness ranging from immediacy (25) to a temporal distance measured in days (26), months (27), even years (28):

(25) C'est le seul être au monde qu'il connait et It is the only being in-the word that he know-PREs-3SG and elle va le laisser dans un monde inconnu où she go-PRES-3Sg him leave-INF in a world unknown where 

elle vient
d'arriver depuis cinq minutes!
she come-PRES-3SG DE
arrive-INF

"She is the only being in the world he knows and she is going to leave him in an unknown world where she has arrived five minutes before."

[Dolto F., La Cause des enfants, 1985]

$$
\begin{aligned}
& \text { [...] cette région du printemps où le voyage de notre } \\
& \text { That region of-the spring where the travel of our }
\end{aligned}
$$

$$
\text { demeure, errant à travers les saisons, venait }
$$

abode, err-PPREs across the seasons come-IMP-3sG

depuis trois jours de l'arrêter sous un ciel clément, [...]

since three days DE it stop-INF under a sky fair

"That region of spring where the travel of our abode, erring across seasons had stopped it for three days under a fair sky, [...]"

[Proust M., À la recherche du temps perdu, 1913]

(27) [...] un jeune homme bien mis, efféminé, [...] il
A young man
well dressed, effeminate [...] he

vient d'arriver depuis deux mois et «il me

Come-PRES-3SG DE arrive-INF since two months and "he me

souhaite bien du plaisir».

wish-PRES-3SG a lot of pleasure".

"A well dressed and effeminate young man [...] he has just been around for 2 months and 'he wishes me good luck."

[Lagarce J.-L., Journal, 2007]

(28) Admiratrice de la maxime: Diviser pour régner, elle Admirer of the maxim: divide-INF for reign-INF, she

d'apprendre, depuis douze ans, à
come-PAST-IMPERF-3SG DE learn-INF, since twelve years, to
$\begin{aligned} & \text { opposer constamment une force à une autre. } \\ & \text { oppose-INF constantly one force to another. }\end{aligned}$

"Admirer of the maxim: Divide and rule, she had just learned over the last twelve years, to constantly oppose one power with another."

[Balzac H. de, Sur Catherine de Médicis, 1846]

The construction venait de + INF + depuis $x$ temps may not feel natural and even awkward to a writer such as Hugo who avoids it by coordinating it with a clause within which the adverbial bears on être:

(29) Il fit

He do-PAST-PERF-3sG

mais quelqu'un fut but someone be-PAST-PERF-3SG more prompt event. It cela avec une promptitude de tigre; with a promptness of tiger; plus prompt encore. Ce 
fut un homme à cheval qui venait

be-PAST-PERF-3SG a man on horse who come-PAST-IMPERF-3SG

d'arriver et qui était depuis quelques

DE arrive-INF and who be-PAST-IMPERF-3SG there since some

instants, sans quon eût fait attention à lui.

instants, without that one have-subJ-IMP do-PP attention to him.

"He did it with the quickness of a tiger but someone was even quicker. It was a man on a horse who had just arrived and had been there for a few moments, without anyone noticing him."

[Hugo V., Quatre vingt-treize, 1874]

v. Even in the 19th and 20th centuries, the adverbials indicating immediate and hodiernal past are the most frequent: both categories represent across centuries $28 / 49$ occurrences, or $57 \%$. The proportion steadily decreases then when prehodiernality is calculated in days ( 9 tokens, 18.3\%), months (4 tokens, $8.1 \%$ ) and years ( 2 tokens, $4.2 \%$ ). In the latter case, the statement comes across as very marked (supra (28)).

Are these trends confirmed by Google searches? We worked on the first 100 occurrences for the ten selected verbs and the results are remarkably similar:

Table 5. Occurrences with postponed adverbials on Google

\begin{tabular}{lcc}
\hline & Occurrences & With postponed adverbial \\
\hline vient de + INF & 1000 & 19 \\
venait de + INF & 1000 & 25 \\
Total & 2000 & 44 \\
\hline
\end{tabular}

$1.9 \%$ of occurrences of vient de + INF are followed by a temporal adverbial, as are $2.5 \%$ of occurrences in venait de + INF. Those 44 tokens are distributed as follows:

Table 6. Distribution of occurrences followed by a temporal adverbial

$\begin{array}{lr}\text { Anteriority } & 15 \\ \text { Immediate } & 8 \\ \text { Hodiernal } & 8 \\ \text { Prehodiernal/day } & 2 \\ \text { Prehodiernal/month } & 0 \\ \text { Prehodiernal/year } & 0 \\ \text { Datation } & 0 \\ \text { Anaphoric reference } & 11 \\ \text { Indefinite } & 44 \\ \text { Total } & \end{array}$


As in the Frantext corpus, the adverbials indicating immediate past and hodiernal past are the most frequent, totalling $23 / 44$ tokens, or $52 \%$. We have found no occurrence of adverbial indicating anteriority in years. Moreover, in all those cases, the adverbial comes after the periphrasis. While anteposition is perfectly possible with a perfective such as a plus-que-parfait (30b), it is difficult with venir $d e+\operatorname{INF}(30 \mathrm{c})$ :

(30a) Le 16 juillet 2009, il a tué son ex-compagne, The 16 July 2009, he have-PREs-3sg kill-pp his former partner, Natacha Holleville - elle venait de le Natacha Holleville - she come-PAST-IMPERF-3Sg DE him quitter 13 jours auparavant - en lui tirant dans leave-INF 13 days before - in to-her shoot-PPREs in le dos avec un fusil de chasse. the back with a gun of hunting. "On July 16, 2009, he killed his former partner, Natacha Holleville - she had just left him 13 days before - by shooting her in the back with a hunting gun."

[La Voix du Nord, 23rd July 2014]

(30b) Le 16 juillet 2009, il a tué son ex-compagne, The 16 July 2009, he have-PREs-3sg kill-pP his formerpartner, Natacha Holleville - 13 jours auparavant elle Natacha Holleville - 13 days before she lavait quitté.

him have-PAST-IMPERF-3SG leave-PP.

"On July 16, 2009, he killed his former partner, Natscha Holleville - she had left him 13 days before."

(30c) ??Le 16 juillet 2009, il a tué son

The 16 July 2009, he have-PREs-3sg kill-pp his ex-compagne, Natacha Holleville - 13 jours auparavant elle formerpartner, Natacha Holleville - 13 days before she venait de le quitter. COMe-PAST-IMPERF-3SG DE him leave-INF.

"On July 16, 2009, he killed his former companion, Natacha Holleville - 13 days before she had just left him."

Let us note however that anteposition cannot be completely ruled out: we found two instances of it in the general corpus, both from the 20th century: 
(31) Le 2 décembre, Pitt tint le même langage à The 2 December, Pitt held-PAst-Perf-3sg the same language to Maret; la veille, il venait de convoquer Maret; the day-before, he come-PAST-IMPERF-3SG DE summon-INF la milice.

the militia.

"On 2nd December, Pitt told the same thing to Maret; only the day before, he had summoned the militia." [Lefebvre G., La Révolution française, 1963]

(32) Jusquà présent, vous avez vu une femme entourée Up to now, you have-PRES-2PL see-PP a woman surrounded de soins et de tendresse, se préoccuper de ses tisanes et de of cares and of tenderness, worry-INF of her infusions and of ses dentelles, mais depuis longtemps je viens her laces, but since a-long-time I come-PREs-1sG

d'abandonner mes manies. DE forsake-INF my odd-habits.

"Until now, you have seen a woman surrounded by care and tenderness worry about her infusions and her laces, but I have just forsaken my odd habits a long time ago."

[GENET J., Les Bonnes, 1959]

As we have shown, this first test only brings minimal support to the hypothesis about the perfective nature of venir de + INF: the temporal adverbial appears sporadically, its anteposition is hardly acceptable and it only rarely expresses an anteriority spanning years.

\subsection{Venir de + INF and when-questions}

In a statement such as (30a), the adverbial 13 jours auparavant specifies the time of parting, from the moment when venir de + INF is used to indicated prehodiernal anteriority, in other words when it cannot specify any more by itself the exact time of the event and needs to rely on an adverbial.

(30a) Le 16 juillet 2009, il a tué son ex-compagne, Natacha Holleville - elle venait de le quitter 13 jours auparavant - en lui tirant dans le dos avec un fusil de chasse.

[La Voix du Nord, 23rd July 2014]

In these types of occurrences, venir de + INF can indeed be seen as on the road to perfectivity. Yet it is still far from having reached its destination if when-questions 
are taken into account. While a past perfective can always be elicited by a when-question:
Quand l'avait-elle
quitté?
When him have-PAST-IMPERF-3SG she leave-PP?
"When had she left him?"

A sentence using venir de + INF cannot (Dominicy 1983:343; Lebaud 1992: 168):
${ }^{*}$ Quand venait-elle
de le quitter?
When come-PAST-IMPERF-3Sg she DE him leave-INF?
"When had she just left him?"

Our corpus includes no such examples, which can be explained by the fact that venir de already provides temporal information of immediate anteriority, so it would be difficult to ask a question about an element that is already available. ${ }^{14}$ Venir de + INF therefore struggles to pass that perfectivity test.

\subsection{Venir de + INF and narrative sequence}

Unlike passé simple, passé composé or présent, ${ }^{15}$ venir de + INF is very rarely used to express narrative sequence: only one occurrence in which two successive clauses in venir de + INF imply narrative sequence has been found in the whole corpus:

Je viens
I come-PRES-1SG DE frouver ta lettre sur la table et je
$\begin{array}{llll}\text { viens } & \text { de finir } & \text { de lire leter on the table and I } \\ \text { come-PRES-1SG DE finish-INF of read-INF your words. One }\end{array}$
va bientôt manger mais je commence quand même go-PRES-3SG soon eat-INF but I start-PRES-1SG anyway to à técrire. you write.

"I have just found your letter on the table and I have just finished reading your words. We are about to eat but I'm starting to write to you anyway."

[Castel H., Retour d'exil d'une femme recherchée, 2009]

However, it is unlikely that the narration would be continued with other occurrences of je viens de + INF. This could be attributed to the fact that the temporal

14. Cf. the question playfully asked to children: "De quelle couleur était le cheval blanc d'Henri IV?" (what was the colour of Henry IV's white horse?).

15. On the compatibility of tenses and narration, see Bres 2009. 
regression expressed by venir de goes against the temporal sequence of a narration. Yet, that explanation would not suffice: a tense such as the plus-que-parfait, that most frequently expresses regression (Damourette \& Pichon, 1970 [1911-1936], tome 5, \$1790; Kamp \& Rohrer 1983:256), can express progression:

(35a) Jacques regarda sa montre, vit qu'il était Jacques watch-PAST-PERF-3SG his watch, see-PAST-IMPERF-3SG quatre heures déjà; et, il se hâta four o'clock already; and he himself hurry-PAST-PERF-3SG de retourner à l'impasse d'Amsterdam. Jusquà midi, of return-INF to the cul-de-sac of Amsterdam. Up to midday, Séverine avait dormi profondément. Séverine have-PAST-IMPERF-3SG sleep-PP deeply.

Ensuite, réveillée, surprise de ne pas le voir là Then, wake-up-PP, surprise of NEG NEG him see-INF there encore, elle avait rallumé le poêle; yet, she have-PAST-IMPERF-3sG relight-PP the stove; et, vêtue enfin, mourant d'inanition, elle and clothe-pP finally, die-pPREs of inanition, she sétait décidée, vers deux heures, herself be-PAST-IMPERF-3sG decide-PP, around 2 o'clock, à descendre manger dans un restaurant du to go-down-INF eat-INF in a restaurant of-the voisinage. Lorsque Jacques parut, elle neighbourhood. When Jacques appear-PAST-PERF-3SG, she venait de remonter, après avoir COME-PAST-IMPERF-3SG DE ascend-INF, after have-INF do-PP fait quelques courses. some shopping. "Jacques had a look at his watch, saw it was already four, and he hurried to go back to the Amsterdam cul-de-sac. Until midday, Séverine was fast asleep. Then, awake and surprised not to see him around, she relit the stove; and with her clothes finally on, dying from inanition, she decided around 2 to go down and eat in a nearby restaurant. When Jacques appeared, she had just gone back up after having done some shopping."

[Zola, E. La Bête humaine]

The pluperfect in "Séverine avait dormi" turns back time from the preceding passé simple "il se hâta". However, the two following plus-que-parfaits indicate a 
progression: elle avait dormi - elle avait rallumé - elle sétait décidée. They may not be replaced by venir de + INF:

*Jusquà midi, Séverine venait de dormir
"Until midday, Séverine come-IMP-SG DE sleep-INF
profondément. Ensuite, réveillée, surprise de ne pas le
deeply. Then, awoke, surprised of NEG him
voir là encore, elle venait de rallumer
see there yet, she come-IMP-SG3SG from relight-INF
le poêle; et, vêtue enfin, mourant
the stove; and clad finally, she come-IMP-SG3sG
d'inanition, elle venait de se décider, vers
from herelf
deux heures, à descendre manger dans un restaurant
2 o'clock, to go down to eat in a restaurant
du voisinage.
of the neighbourhood."

Venir de + INF cannot be used in a narrative sequence because it lacks autonomy: it can only indicate the anteriority of an event in relation to another one yet; unlike the plus-que-parfait, it cannot indicate a progression from an event to another.

Venir de + INF can hardly meet the requirements for perfectivity: while it may be combined with temporal complements, it is rare and they come almost exclusively after the verbal form; it cannot be used in a when-question; it cannot be used to express narrative sequence. Contrary to Vetters, we suggest that venir de + INF remains at heart a marker of immediate anteriority. On the grammaticalisation path, its evolution towards a perfective, subtly hinted at in the 19th century, is not confirmed in contemporary daily written language and its use with this meaning remains extremely restricted.

\section{Immediate anteriority, anteriority, bis-anteriority, immediate ulteriority}

In this section, we discuss the relation of venir de + INF with the grams of anteriority, bis-anteriority and immediate ulteriority.

\subsection{Immediate anteriority, anteriority, bis-anteriority}

As we have already seen, venir de (+ INF) as well as être/avoir (+ PP) are aspectual auxiliaries that account for the post-process stage. Yet, unlike venir de + INF, 
être/avoir + PP imply no mention of the degree of remoteness. Let us compare (1a) and (1b):

(1a) Mon copain vient de rompre et j’arrive pas à l'accepter.

[teemix.aufeminin.com, 2008]

$\begin{array}{llll}\text { Mon copain } a & \text { rompu et jarrive pas } \\ \text { My boyfriend have-PREs-3sG break-off-PP and } & \text { I cannot } \\ \text { à l'accepter. } & & \\ \text { accept it. } & & & \\ \end{array}$

"My boyfriend has just ended our relationship and I can't accept it."

The passé composé shows the event interval rompre as anterior to the reference interval, but unlike vient de, it does not specify a temporal distance between both intervals:

vient de rompre: $\mathrm{R}_{1}-\mathrm{R}_{2} \subset \varepsilon_{1}-\varepsilon_{2} ; \mathrm{E}_{2}<\mathrm{R}_{1} ; \mathrm{R}_{1}-\mathrm{R}_{2}, \mathrm{~S}_{1}-\mathrm{S}_{2}$ (the reference interval $\mathrm{R}_{1}-\mathrm{R}_{2}$ is included within the interval of the venir $\varepsilon_{1}-\varepsilon_{2}$ process, the final limit $\mathrm{E}_{2}$ of the rompre event is immediately anterior to the initial limit $\mathrm{R}_{1}$; the reference interval and the speech interval coincide).

a rompu: $\mathrm{R}_{1}-\mathrm{R}_{2} \subset \varepsilon_{1}-\varepsilon_{2} ; \mathrm{E}_{2}-\mathrm{R}_{1}$ et $\mathrm{R}_{1}-\mathrm{R}_{2}, \mathrm{~S}_{1}-\mathrm{S}_{2}$ (the reference interval $\mathrm{R}_{1}-\mathrm{R}_{2}$ is included within the interval of the venir $\varepsilon_{1}-\varepsilon_{2}$ process, the final limit $\mathrm{E}_{2}$ of the rompre event is anterior to the initial limit $\mathrm{R}_{1}$; the reference interval and the speech interval coincide)

The distinction is confirmed in that, unlike vient de rompre, a rompu combines without any problem with an anteposed adverbial indicating a prehodiernal distance going back to years:

(1c) Ilya deux ans, mon copain a rompu et jarrive There-is two years, my boyfriend have-PREs-3sG and I manage (toujours) pas à laccepter (still) not to it accept.

"Two years ago, my boyfriend ended our relationship and I (still) don't manage to accept it."

(1d) ?Ily a deux ans, mon copain vient de Two years ago, my boyfriend come-PREs-SG3sg from

$\begin{array}{llll}\begin{array}{l}\text { rompre } \\ \text { break-off-INF }\end{array} \text { and I } & \text { (still) } & \text { dont laccepter. } \\ \text { don't manage to accept it. }\end{array}$
* "Two years ago, my boyfriend has just ended our relationship and I (still) don't manage to accept it." 
At a morphological level the following correspondences can be found:

$\begin{array}{ll}\text { Immediate anteriority } & \text { Anteriority } \\ \text { vient de rompre } & \text { a rompu (passé composé) } \\ \text { venait de rompre } & \text { avait rompu (plus-que-parfait) } \\ \text { viendra de rompre } & \text { aura rompu (futur antérieur) } \\ \text { viendrait de rompre } & \text { aurait rompu (conditionnel passé) } \\ \varnothing & \text { eut rompu (passé antérieur) }\end{array}$

The avoir $+p$. passé paradigm is not defective. In particular, it includes the passé antérieur, namely an anterior to the passé simple, while this tense is impossible for venir de, as shown above:

(36) Dès qu'il fut sorti, elle fut reprise par la même impatience de le revoir que tout à l'heure. ( ${ }^{*}$ dès qu'il vint de sortir)

As soon as he be-PAST-PERF-3SG go-out-PP, she be-PAST-PERF taken-againpP by the same impatience of him see-again-INF as earlier.

"As soon as he was out, she was filled with the same impatience to see him as she had been earlier."

[Duras M., Les Impudents, 1946]

We have explained the defectivity of venir de in the passé simple and in compound forms by the fact that the tenses that combine with venir cannot create a space between $\mathrm{E}_{2} \leftrightarrow \mathrm{R}_{1}$. Etre and avoir $(+p p)$ are not required to clear that space and can therefore be conjugated in the passé simple as in (36). That is:

Il fut sorti: $\mathrm{R}_{1}-\mathrm{R}_{2}, \varepsilon_{1}-\varepsilon_{2}$ et $\mathrm{R}_{1}, \mathrm{E}_{2}$ et $\mathrm{R}_{2}-\mathrm{S}_{1}$ (the reference interval $\mathrm{R}_{1}-\mathrm{R}_{2}$ coincides with the event interval être $\varepsilon_{1}-\varepsilon_{2}$; the initial limit $R_{1}$ coincides with the final $E_{2}$ of the sortir event, and the final limit $\mathrm{R}_{2}$ is anterior to the speech interval)

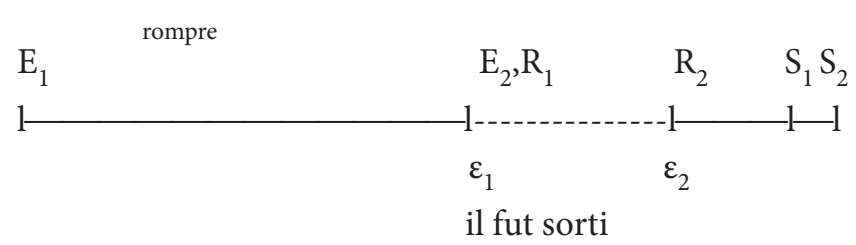

Figure 6. Representation of fut sorti in our revised Reichenbachian model

We make one further note about the passé composé: Is the grammaticalisation of venir into an auxiliary, stabilized in the 17th century, linked with the evolving passé simple/passé composé dyad? That hypothesis is perfectly conceivable on the famous 24-hour rule suggested by Henri Estienne (1569), adopted by the Port Royal Grammar (Lancelot \& Arnaud 1660), and still accepted today by some, like Comrie (1985:93) or Bybee et al. (1994:101). According to that rule, the passé composé is reported to have been used in the 16th and 17th centuries solely to 
convey events that had taken place on the day of speech, while the passé simple was required for prehodiernal events. That temporal distribution of passé simple and passé composé evolved at the turn of the 17-18th centuries when the passé composé became able to refer to events that had taken place before the day of speech. One might suggest that the acceptance of venir de + INF as an IMMEDIATE anterior in the 17th century came from the progressive rejection of the hodiernal constraint by the passé compose, that created a need for another form for expressing immediate anteriority. However, we reject that hypothesis for a number of reasons.

Wilmet (1970), Fournier (1998) and Liu \& Caron (1999) show that the 24-hour rule did not reflect usage. Until the 17th century, the passé composé was used for any event including the speech interval; otherwise, the passé simple was needed:

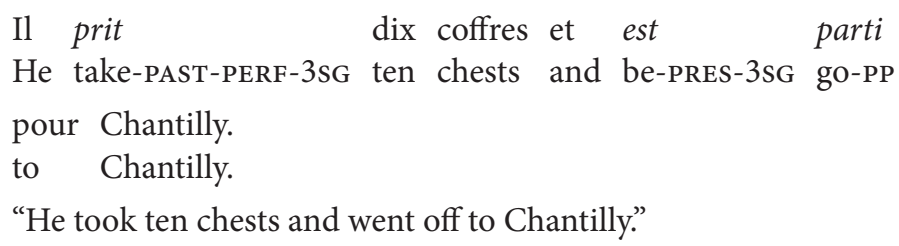

[Mme de Sévigné, Lettres, 1725]

After a passé simple Mme de Sévigné uses the passé composé for a prehodiernal event because the agent is still in Chantilly at the time of writing. The passé composé was not hodiernal and could be combined with any adverbial such as aujourd'hui "today", cet été "this summer", cette année "this year", etc. but not with hier "yesterday", la veille "the day before", etc. That is: cette année, il a beaucoup plu "this year it rained a lot" but hier il plut "yesterday, it rained". The distinction between passé simple/passé composé was not of a temporal nature, but of an enunciative nature. That enunciative difference intensified from the 17 th century onwards: increasingly, the PS could no longer be used with a deictic adverb such as hier (hier il plut), and was replaced by the PC (hier il a plu). The emergence of the periphrastic structure to express an immediate anterior could not be linked to the fact that the PC lost its hodiernal dimension, given that the PC was not hodiernal.

The potential link between the periphrastic structure in venir de + INF and the evolution of the PC may be valid for the contemporary period: il vient de pleuvoir/ il a plu. Yet, the structure appears in the imperfect- il venait de pleuvoir - and it could not be linked with the evolution of the plus-que-parfait.

If there was a link between the periphrastic structure and the evolution of the passé composé, we would expect vient de + INF to compete extensively with the PC for the expression of recent past. Yet, this is not the case: unlike the periphrastic future (Pierre va venir demain) that fiercely competes with the synthetic future (Pierre viendra demain), vient de + INF has remained sporadic since the 
17th century. To retell a recent event, the PC or the present are used, not vient de + INF because, as seen in $\$ 3$, the periphrasis expresses an anterior, not a perfective.

Finally, if there were a causative link between the periphrastic construction and the evolution of the PC in French, we would expect the immediate anterior of Catalan (acaba de ploure) and Spanish (acaba de llover), to work differently than in French, given that their compound past does not share the values of the French passé composé. However, this is not the case; the immediate anterior works in similar ways in all three Romance languages. For these reasons, we do not find it appropriate to link the emergence of venir + INF with the evolving competition between passé composé/passé simple in the 17th century. Besides, venir de is defective in compound forms, unlike être/avoir + PP, which benefit from a surcompound paradigm: ${ }^{16}$

$\begin{array}{lll}\begin{array}{ll}\text { Immediate anteriority } \\ \text { vient de rompre }\end{array} & \text { anteriority } & \text { bis-anteriority } \\ \text { venait de rompre } & \text { avait rompu } & \text { a eu rompu } \\ \text { viendra de rompre } & \text { aurait eu rompu } \\ \text { viendrait de rompre } & \text { aurait rompu } & \text { aura eu rompu } \\ \varnothing & \text { eut rompu } & \text { eut eu rompu }\end{array}$

Without analysing the meaning of surcompound forms (among others Wilmet 2009, Apothéloz 2012), let us note that in addition to a meaning of bisanterior (38) (Damourette \& Pichon 1911-1936 /1970 \$1775 et sq.), Franco-Provençal and Francitan use the passé surcomposé to express remote anteriority (39):

$$
\begin{aligned}
& \text { Il a repris un peu de ses sens quand } \\
& \text { He have-PREs-3sg take-back-PP a bit of his senses when } \\
& \text { Parapine lui } a \quad \text { eu fait sa piqûre } \\
& \text { Parapine him have-PRES-3SG have-PP make-PP an injection } \\
& \text { de morphine. } \\
& \text { of morphine. }
\end{aligned}
$$

"He came back to his senses a bit after Parapine gave him an injection of morphine."

[Céline L.-F., Voyage au bout de la nuit, 1932]

$$
\begin{aligned}
& \text { J'ai eu parlé patois // mais } \\
& \text { I have-PRES-3sG have-PP speak-PP dialect but } \\
& \text { maintenant plus } \\
& \text { now not-anymore }
\end{aligned}
$$

"I used to speak dialect but now I don't anymore."

[conversation, Montpellier, 2008]

16. Surcompound forms, attested since the Middle Ages, were described as early as the 16th century and labeled as such in the 18th century (Wilmet 2010:193, \$184). 
French thus has at its disposal, beside venir de + INF, a gram of immediate anteriority, grams of anteriority made of être/avoir $+p$. passé that do not indicate any degree of remoteness. It also has grams of bis-anteriority that, in some varieties, can also indicate remote anteriority: these surcompound forms made of the compound form of the auxiliary p. passé, are little used, with the exception of the passé surcomposé.

\subsection{Other grams of immediate anteriority}

Two other grams of immediate anteriority developed in the 16th century: ne faire que de + INF, and sortir de:

(40) Despesche-toy de descendre et de mouvrir hurry yourself to come-down-INF and to me open-INF la porte si tu veux sauver ta vie et l'honneur de the door if you want-PRES-2sG save-INF your life and the honour of ta maistresse! Car je te puis asseurer que Dame Louyse your mistress. Because I you can assure that Dame Louise ne fait que de partir d'icy.

NEG make-PRES-3SG only DE leave-INF.

"Hurry to come down and to open the door for me if you want to save your life and the honour of your mistress. Because I can assure you that Lady Louise has only just left this place." [Turnèbe O. de, Les Contens, 1584]

(41) Je sortais de voir au Pitti la

I come-out-PAST-IMPERF-1SG from see-INF at-the Pitti the Simonetta, maîtresse fameuse du magnifique, peinte Simonetta, mistress famous of-the magnificent, paint-PP-FSG par Botticelli.

by Boticelli.

"I had just seen at the Pitti la Simonetta, famous lover of the Magnificent, painted by Botticelli."

[Barrès M., Un homme libre, 1889]

Far less frequent than venir de + INF, these grams never really posed a threat and actually became obsolete in the 20th century. Indeed, only one of these grams remains in the popular expression sortir d'en prendre "to have just undergone sth":

(42) - Pourquoi cette rage à paraître plus lâche que vous nềtes?

- Plus lâche? Oh ! Là là, ne remettez pas la conversation là-dessus, voulezvous? Je sors d'en prendre.

- why that rage to look-INF more coward than you NE be-PRES-2PL?

- more cowardly? oh! là là, NEG bring-back-IMPER-2PL NEG the conversation there-upon, want-PRES-2PL you? 
“- Why that rage to appear more cowardly than you are?

- More cowardly? Oh dear, don't bring the conversation back on this, will you? I have taken a beating [I come out from of something take-INF]."

[Bernanos G., Un mauvais rêve, 1948]

Another gram can also be found from the 16th through the 19th century when it becomes obsolete, is the expression ne venir que de, that can be analysed as mixing ne faire que de and venir de (Dominicy 1983:344):

On prétend que ce mariage étoit fait One claim-PRES-3SG that that marriage be-PAST-IMPERF do-PP il y déjà quelques mois, mais on ne vient que there is already several months, but one NEG come-PRES-3sG only

de l'apprendre ici par les lettres de Hollande et de Flandre. of it learn here by the letters of Holland and Flanders "It is claimed that the marriage took place already a few months ago but we have only just heard about it here through letters from Holland and Flanders."

[Dangeau P. de, Journal, 1713]

In the same way as venir de and for the same reasons, these structures were defective: they cannot be conjugated in the passé simple in the indicative mood nor in any compound tenses irrespective of the mood.

\subsection{Immediate anteriority and (immediate) ulteriority}

It is customary to draw parallels between immediate anteriority resulting from the grammaticalisation of the movement verb venir with immediate ulteriority resulting from the grammaticalisation of the movement verb aller: il vient de pleuvoir/il va pleuvoir. Without reviewing all the similarities and differences between both structures (Damourette \& Pichon 1970 [1911-1936], Gougenheim 1971 [1929], Havu 2005), we focus here on their aspectual dimension and their feature of immediacy.

Contrary to what is often claimed, aller here is not a temporal auxiliary but an aspectual auxiliary: while venir $(+d e)$ relates to the post-process phase, aller relates to the pre-process phase and, according to the tense used, this can mean ulteriority in the present (il va pleuvoir) or in the past (il allait pleuvoir). ${ }^{17}$

The structure in the present (va pleuvoir), sporadic in the 13th century, spreads in the 15th century with a meaning of immediate ulteriority. From the 17th century onwards, it has increasingly freed itself - at least in part - from this meaning of

17. Va + INF is more defective than venir de + INF: in the indicative, it can only be conjugated in the présent and imparfait while it only admits simple tenses in the other moods. 
immediacy and it has grammaticalised from a proximal ulterior into a future (Fleischman 1983: 193): nowadays, it is in fierce competition with the simple future - it is able to combine with an adverbial expressing remoteness - and the difference expressed by the periphrastic form has less to do with "la proximité chronologique de lévénement [the chronological proximity of the event]" than with the "point de vue présent dont on considère cet événement! [the present point from which the event is viewed]" (Damourette \& Pichon 1970 [1911-1936], \$1768):

Mais arrête! dans dix ans tu vas encore
But stop-IMPER-2sG! in ten years you go-PRES-2SG stil
t'occuper de moi comme si jétais $\quad$ un bébé!
yourself occupy-INF of me as-if I be-PAST-IMPERF-1sG a baby!
"But stop! In ten years' time you will still look after me as if I were a baby."
[conversation, a 13-year old teenager addressing his mum, 2000]

Unlike the ulteriority gram $v a+$ INF that is in strong competition with the future (at least in temporal meanings) because it has dissociated itself from immediacy, venir de + INF remains an immediate anterior at heart: in its use in the present (vient de + INF), it does not really compete with the passé composé.

\section{Immediate anteriority in French and in other Romance languages}

Let us underline the (relative) distinctiveness of French within Romance languages by examining the resources used on the basis of a translation of example (1a) "mon copain vient de rompre" ["My boyfriend has just ended our relationship"]:

- OCCITAN is the only one to convey immediate anteriority with the ventive form (1e):

(1e) Mon companh ven de copar. (Occitan)

- ItALian has attempted the structure (1f), before it was condemned in the 19th century ${ }^{18}$ as a Gallicism:

(1f) Il mio ragazzo viene di mollarmi. (Italian until 18th century)

18. Beauzée (1767, in Gougenheim 1929:125) mentions the pervasiveness of the French structure in 18th century Italian: "depuis quelque temps, on dit en italien, io vengo di lodare, io venivo di lodare, etc., cette expression est un gallicisme, qui a été blâmé par M. l'abbé Fontanini; mais l'autorité de l'usage l'a enfin consacré dans la langue italienne qui se trouve ainsi pourvue, comme la nôtre, des prétérits prochains" "for some time now, it is said in Italian io vengo di lodare, io venivo di lodare, etc., this structure is a Gallicism that has been criticised by Abbott Fontanini; however the power of usage has finally established it within the Italian language that as a result has at its disposal, like French, proximal preterits". 
Nowadays, Italian expresses immediate anteriority with an adverb (appena, (1g)) combined with the compound form of the verb as does Romanian (tocmai (1h)):

(1g) Il mio ragazzo mi ha appena mollato. (Contemporary Italian)

(1h) Prietenul meu tocmai $m-a$ parasit. (Romanian)

This way of expressing immediate anteriority is akin to what is found in Germanic languages: just (English), gerade (German) + PERFECT (Tovena \& Shaden 2009). Let us mention that it is also possible in French mainly in the syntactical structure of correlation être/avoir à peine + p. passé que $P$ :

(45) Elle sanglota toute la route en retournant à la ferme, et elle était à peine revenue que son maitre l'appela dans sa chambre.

She sob-PAST-PERF-3sG all the road in go-back-PPRES to the farm, and she be-PAST-IMPERF-3SG only-just come-back-PP

"She sobbed all the way back to the farm and she had only just come back when her master summoned her to his room."

[Maupassant G., Histoire d'une fille de ferme, 1881]

The Ibero-Romance languages - Catalan, Spanish, Portuguese - have opted, like French, for the auxiliary followed by the de preposition but from the grammaticalisation of acabar "complete", "finish":

(1i) El meu novio m'acaba de deixar. (Catalan)

(1j) Mi novio acaba de dejarme. (Spanish)

(1k) O meu namorado acaba de deixar-me. (Portuguese)

In contrast to ventive forms, the development path of a dynamic verb such as finish leads to anteriority through a completive stage (Bybee et al. 1994: 105) that can always remain:

'finish' $\rightarrow$ completive $\rightarrow$ ANTERIOR

Acabar de is ambiguous when followed by an activity or accomplishment as it can mean "finish doing something" (completive) or "have just done something" (anterior):

(46a) Cat.: Rosa acaba de preparar l'arròs,

(46b) Sp.: Rosa acaba de preparar el arroz.

(46c) Port.: A Rosa acaba de cozinhar o arroz.

In all three languages, this sentence can mean "Rosa finishes preparing the rice" as well as "Rosa (has) just prepared the rice". To avoid ambiguity, the completive meaning is often conveyed by the progressive in Catalan and Spanish:

(46d) Cat.: Rosa està acabant l'arròs.

(46e) Sp.: Rosa está acabando el arroz. 
Spanish is increasingly using terminar to express immediate anteriority:

(47) Terminamos de llegar mi familia y yo de Morella. We finish-PRES-1PL of arrive-INF my family and I from Morella. "We have just arrived my family and I from Morella."

[http://www.toprural.com/Victor-Martin/opini\%C3\% B3n-Apartamentos-Rojo-Y-Naranja_veinticuatro0149_o.html. Consultado el 18/04/2014) (apud Martinez-Atienza forthcoming)]

Besides, it must be noted that the venir de + INF construction, stigmatized as a Gallicism, is currently developing in contemporary Asturian, Galician and in several areas of Hispanoamérica (Argentina, Uruguay), ${ }^{19}$ particularly in sports reporting. In the following occurrence, the immediate anteriority of the process proclamarse is indicated in the title by venir de and within the article by acabar de:

(48) El deportista guardés Damián Alonso Alonso viene de The athlete Damián Alonso Alonso come-Pres-3sg DE proclamarse campeón europeo de remo ergométro. be proclaimed-INF champion European of rowing indoors. "The athlete Damián Alonso has just been proclaimed European champion for indoor rowing."

Damian Alonso, que en la actualidad ejerce de entrenador en Damián Alonso, who in the actuality, acts as coach in nuestro club, se acaba de proclamar campeón our club come-PRES-3SG DE be proclaimed-INF champion europeo de remo ergómetro. European of rowing indoors.

"Damián Alonso, a coach in our club, has just been proclaimed European champion for indoor rowing."

[www.todoremo.com, 28. 1.2013]

Note that acabar as immediate anterior can be conjugated in the present and the imparfait but not in the preterit nor in the present perfect. In those tenses, it can only be interpreted as a COMPLETIVE:

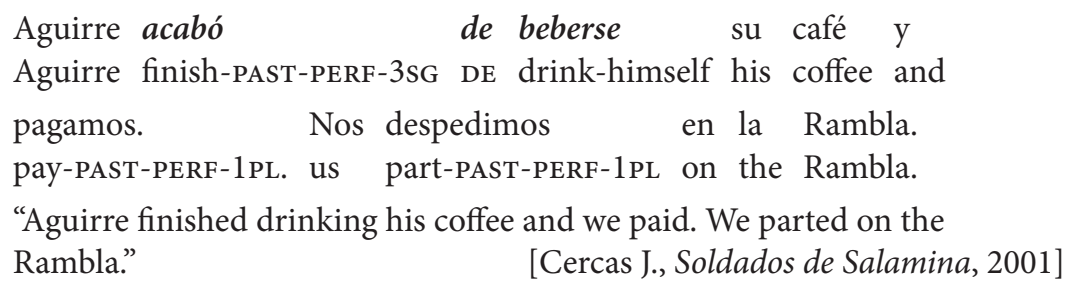

19. We are grateful to Sophie Azzopardi, Carmen Garabato and Sophie Sarrazin for bringing that emerging usage to our attention. 
(50) Personalmente no me considero una mujer que personally NEG me see-PRES-1SG a woman who quiera volver a trabajar sólo porque want-PRES-3SG turn-INF to work-INF because have-PRES-SG ha acabado de criar a sus hijos. finish-PP DE raise her sons.

"I don't personally see myself as a woman who wants to find employment because she has finished raising her children."

[Diario de León.es., 2004-09-05]

Romance languages all express immediate anteriority but in ways that are distinct from French: by an adverb (Italian, Romanian), by the grammaticalisation in an auxiliary not of venir but of acabar (Catalan, Spanish, Italian). There is no apparent link between the compound past in those languages and the expression chosen to express immediate anteriority: Italian has a PC close to the French PC that expresses immediate anteriority by an adverb (appena) in the same way as Germanic languages (just, gerade); Spanish and Catalan have a PC that works differently from the French, but they express immediate anteriority by a periphrasis consisting of a verb turned into an auxiliary (acabar).

\section{Conclusion}

While analysing the grammaticalisation of venir over time, we have shown that venir in venir de + INF was an aspectual auxiliary of immediate anteriority rather than a temporal auxiliary of recent past, and we have accounted for its defectivity. On the basis of the (revised) Reichenbachian model (the three constructs: $E$ (= event point), $S$ (= speech point) and $R$ (= reference point)), we have explained that it is the aspectual relation between the reference interval $R_{1}-R_{2}$ and the event interval $\varepsilon_{1}-\varepsilon_{2}$ of venir in its relation with the event interval E1- $\mathrm{E}_{2}$ for the infinitive that allows venir (de) to be conjugated in some tenses (présent, imparfait, conditionnel, futur), but not in others (passé simple, compound tenses).

We have shown that venir de + INF, contrary to Vetters (2010), is not far advanced on the grammaticalisation path from ANTERIOR to PERFECTIVE: it has only sporadically been combined with a prehodiernal adverbial since the 19th century and the trend has not further intensified in Contemporary French; it cannot be used in a when-question nor to express narrative sequence. Venir de + INF remains at heart a marker of immediate anteriority.

French has at its disposal, beside venir de + INF, grams of anteriority consisting of être/avoir $+p$. passé in which the être and avoir auxiliaries can be conjugated 
in all tenses, in particular in the passé simple (quand il fut venu, quand il eut fini) because they do not indicate any degree of remoteness (passé antérieur, plus-queparfait, future antérieur, conditionnel passé). In contrast, venir de + INF does not compete with these markers of anteriority, unlike what has happened with immediate ulteriority. Indeed, aller + INF has progressively distanced itself from the meaning of immediacy, which has allowed - especially in the présent (e.g., il va pleuvoir) - an increasing competition with the futur (il pleuvra) since the 19th century. Unlike aller + INF, which is widespread, venir de is comparatively not very frequent: as it keeps its value of immediate anteriority, it does not compete with compound tenses that indicate anteriority without any degree of remoteness thanks to the être and avoir auxiliaries, nor with the passé composé in its value of PERFECTIVE.

Finally, when comparing venir de + INF with structures used in other Romance languages to express immediate anteriority, it has been shown that Italian and Romanian convey it through adverbs (appena, tocmai) combined with the compound form of the verb like what is found in Germanic languages: just (English), gerade (German) + PERFECT. Other Iberian Romance languages - Catalan, Spanish, Portuguese - have opted, like French, for the auxiliary followed by the de preposition but they have grammaticalised acabar instead of venir. Finally, only Occitan uses, like French, the ventive form venir de, even if Italian attempted to develop it in the 18th century and it emerges nowadays in some Iberian Romance languages.

So to conclude, our brief comparison of French with other Romance Languages shows that immediate anteriority can be expressed by significantly different syntactic means (adverbial indications, various movement verbs) within a language family while each of those means seems be found in typologically unrelated languages. In addition, external influences such as normative judgments may alter grammaticalisation paths. The trends we have identified will now benefit from being tested against evidence from other languages.

\section{Abbreviations}

$\begin{array}{llll}\text { COND } & \text { conditionnel } & \text { PC } & \text { passé composé } \\ \text { F } & \text { feminine } & \text { PERF } & \text { perfective } \\ \text { IMP } & \text { imparfait } & \text { PL } & \text { plural } \\ \text { IMPER } & \text { impératif } & \text { PP } & \text { participe passé } \\ \text { IMPERF } & \text { imperfective } & \text { PPRES } & \text { participe présent } \\ \text { INF } & \text { infinitif } & \text { PRES } & \text { présent } \\ \text { M } & \text { masculine } & \text { PS } & \text { passé simple } \\ \text { NEG } & \text { negation } & \text { SG } & \text { singular } \\ \text { PAST } & \text { past } & & \end{array}$




\section{References}

Apothéloz, Denis. 2012. La concurrence du passé composé et du passé surcomposé dans l'expression de la valeur de parfait d'expérience. In Louis de Saussure \& Alain Rihs (eds.), Etudes de sémantique et pragmatique françaises, 39-65. Bern: Peter Lang.

Barceló, G. Joan \& Jacques Bres. 2006. Les temps de l'indicatif. Paris: Ophrys.

Beauzée, Nicolas. 1767. Grammaire générale. Paris: Barbou.

Benveniste, Emile. 1966 [1959]. Les relations de temps dans le verbe français. Problèmes de linguistique générale. 237-257. Paris: Klincksieck.

Bourdin, Philippe. 1999. Venir de et la récence: un marqueur typologiquement surdéterminé. Cahiers Chronos 4. 203-231.

Bourdin, Philippe. 2005. Venir en français contemporain: de deux fonctionnements périphrastiques. In Hava Bat-Zeev Shyldkrot \& Nicole Le Querler (eds.), Les périphrases verbales, 261-278. Amsterdam: John Benjamins. doi:10.1075/lis.25.2obou

Bourdin, Philippe. 2008. On the grammaticalization of 'come' and 'go' into markers of textual connectivity. In Maria-Jose Lopez-Couso \& Elena Seoane (eds.), Rethinking grammaticalization: New perspectives, 37-59. Amsterdam: John Benjamins. doi:10.1075/tsl.76.05bou

Bres, Jacques. 2009. De l'interaction avant toute chose ... Temps verbaux et relation de progression. Cahiers Chronos 21. 45-64.

Bres, Jacques \& Emmanuelle Labeau. 2012. De la grammaticalisation des formes itive (aller) et ventive (venir): valeur en langue et emplois en discours. In Louis de Saussure \& Alain Rihs (eds.), Etudes de sémantique et pragmatique françaises, 143-165. Bern: Peter Lang.

Bres, Jacques \& Emmanuelle Labeau. 2013. Aller et venir: des verbes de déplacement aux auxiliaires aspectuels-temporels-modaux. Langue française 179. 13-28.

Bybee, Joan, Revere Perkins \& William Pagliuca. 1994. The evolution of grammar: Tense, aspect, and modality in the languages of the world. Chicago: The University of Chicago Press.

Comrie, Bernard. 1976. Aspect. Cambridge: Cambridge University Press.

Comrie, Bernard. 1985. Tense. Cambridge: Cambridge University Press. doi:10.1017/CBO9781139165815

Dahl, Östen. 1983. Temporal distance: Remoteness distinctions in tense-aspect systems. Linguistics 263. 105-122. doi:10.1515/ling.1983.21.1.105

Dahl, Östen. 2000. The tense-aspect systems of European languages in a typological perspective. In Östen Dahl (ed.), Tense and aspect in the languages of Europe. 3-25. Berlin: Mouton de Gruyter. doi:10.1515/9783110197099.1.3

Damourette, Jacques \& Edouard Pichon. 1970 [1911-1936]. Des mots à la pensée: Essai de grammaire de la langue française (Tome 5). Paris: D’Artrey.

De Mulder, Walter. 2010. La métaphore espace/temps à l'épreuve: lévolution de venir de. Cahiers Chronos 21. 65-83.

Dik, Simon Cornelis. 1989. The theory of functional grammar. Dordrecht: Foris.

Dominicy, Marc. 1983. Time, tense and restriction (on the French periphrasis venir de + infinitive). Communication \& Cognition 16, 1(2). 133-154.

Estienne, Henri. 1569. Traicté de la conformité du langage francois avec le Grec. Paris: Dupuis.

Fleischman, Suzanne. 1983. From pragmatics to grammar: Diachronic reflections on complex pasts and futures in Romance. Lingua 60. 183-214. doi:10.1016/0024-3841(83)90074-8 Flydal, Leiv. 1943. 'Aller' et 'venir de' comme expressions de rapports temporels. Oslo: Dybwad. Fournier, Nathalie. 2002 [1998]. Grammaire du français classique. Paris: Belin. 
Givon, Talmy. 1982. Tense-aspect-modality: The creole proto-type and beyond. In Paul Hopper (ed.), Tense-aspect: Between semantics and pragmatics, 115-163. Amsterdam: John Benjamins.

Gosselin, Laurent. 1996. Sémantique de la temporalité en français. Louvain-la Neuve: Duculot.

Gosselin, Laurent. 2011. Laspect de phase en français: le rôle des périphrases verbales. Journal of

French Language Studies 21(3). 149-171. doi:10.1017/So959269510000359

Gougenheim, Georges. 1971 [1929]. Etudes sur les périphrases verbales de la langue française. Paris: Nizet.

Guillaume, Gustave. 1970 [1929]. Temps et verbe. Paris: Champion.

Hagège, Claude. 1993. The language builder. Amsterdam: John Benjamins. doi:10.1075/cilt.94

Havu, Jukka. 2005. L'expression du passé récent en français: observations sur l'emploi de la périphrase venir + INFINITIF. In Hava Bat-Zeev Shyldkrot \& Nicole Le Querler (eds.), Les périphrases verbales, 279-292. Amsterdam: John Benjamins.

Heine, Bernd. 2003. Grammaticalization. In Brian Joseph \& Richard Janda (eds.), The handbook of historical linguistics, 575-601. Oxford: Blackwell.

Heine, Bernd \& Tania Kuteva. 2002. World lexicon of grammaticalization. Cambridge: Cambridge University Press. doi:10.1017/CBO9780511613463

Hopper, Paul J. \& Elizabeth Closs Traugott. 1993.Grammaticalization. Cambridge, England: Cambridge University Press.

Kamp, Hans \& Christian Rohrer. 1983. Tense in texts. In Ranier Bäuerle, Christoph Schwarze, \& Arnim von Stechow (eds.), Meaning, use and interpretation of language, 250-269. Berlin: Walter de Gruyter.

Klein, Wolfgang. 1994. Time in language. London: Routledge.

Lamiroy, Béatrice. 1983. Les verbes de mouvement en français et en espagnol. Amsterdam: John Benjamins. doi:10.1075/lis.11

Lancelot, Claude \& Antoine Arnaud. 1660. Grammaire générale et raisonnée. Paris: Pierre le Petit. Langacker, Ronald Wayne. 1986. Abstract motion. In Vassiliki Nikiforidou, Mary VanClay, Mary Niepokuj, \& Deborah Feder (eds.), Proceedings of the Twelfth Annual Meeting of the Berkeley Linguistics Society, 445-471. Berkeley: Berkleley Linguistics Society.

Lebaud, Daniel. 1992. Venir de + infinitif: localisation d'un procès dans un passé récent ou spécification d'un état actuel? Le Gré des langues 4. 162-175.

Liu, Yu-Chang \& Philippe Caron. 1999. Nouvelles données sur la concurrence du passé simple et du passé composé dans la littérature épistolaire. L'information grammaticale 82. 38-50.

Martínez-Atienza, Maria. Forthcoming. Acabar de + infinitivo como perífrasis temporal y aspectual. Contraste con el italiano y proceso de gramatización en obras lexicográficas.

Reichenbach, Hans. 1966. [1947]. Elements of symbolic logic. New York: Free Press.

Tournadre, Nicolas. 2004. Typologie des aspects verbaux et intégration à une théorie du TAM. Bulletin de la Société de Linguistique de Paris. 7-68. doi:10.2143/BSL.99.1.541909

Tovena, Lucia \& Gerhard Schaden. 2009. Immediate anteriority with and without scales. Paper presented at the Chronos 9 conference, Paris, France, Sept. 2-4.

Vendler, Zeno. 1967. Verbs and time. In Linguistics in philosophy, 97-121. London: Cornell University Press.

Vetters, Carl. 1989. Grammaticalité au passé récent. Lingvisticae investigationes 13(2). 369-386.

Vetters, Carl. 2002. Remarques sur l'analyse reichenbachienne des temps verbaux. Romanica Wratislaviensia 49. 93-132.

Vetters, Carl. 2010. Développement et évolution des temps du passé en français: passé simple, passé composé et venir de + infinitif. In Estelle Moline \& Carl Vetters (eds.), Temps, aspect et modalité en français (Cahiers Chronos 21). 277-298. 
Wilmet, Marc. 1970. Le système de l'indicatif en moyen français. Geneva: Droz.

Wilmet, Marc. 2009. Le passé surcomposé sous la loupe. Journal of French Language Studies 19(2). 381-399. doi:10.1017/S0959269509990056

Wilmet, Marc. 2010. Grammaire critique du français, 5th edn. Bruxelles: De Boeck-Duculot.

\section{Résumé}

Cet article développe l'idée que, dans le tour venir de + INF, le verbe venir s'est grammaticalisé en auxiliaire aspectuel d'antériorité. On s'oppose ainsi à l'approche traditionnelle selon laquelle venir de + INF exprimerait le passé récent et constituerait un auxiliaire temporel. Sur la base du modèle reichenbachien (révisé), on y montre que venir de + INF porte sur la relation entre $\mathrm{R}$ et $\mathrm{E}$ (aspect) et non sur la relation entre $\mathrm{R}$ et $\mathrm{S}$ (temps). Cette analyse permet d'expliquer pourquoi venir, dans cette périphrase, est un verbe défectif (sans formes de passé simple ni de temps composé).

\section{Zusammenfassung}

Dieser Aufsatz untersucht die Grammatikalisierung von venir als aspektuelles Hilfsverb, das unmittelbare Vorzeitigkeit ausdrückt, entgegen der traditionellen Ansicht (Gougenheim (1971 [1929])), nach der venir de + INF die jüngere Vergangenheit ausdrückt und daher als temporales Hilfsverb gilt. Basierend auf dem (überarbeiteten) Modell von Reichenbach wird gezeigt, dass venir de + INF auf die Beziehung zwischen $\mathrm{R}$ und $\mathrm{E}$ (Aspekt) einwirkt, nicht jedoch auf jene zwischen R und S (Zeit). Mithilfe dieser Analyse lässt sich erklären, warum venir in dieser Periphrase einen Defekt aufweist (d.h. warum venir nicht im passé simple oder einer zusammengesetzten Zeitform konjugierbar ist).

\section{Corresponding author's address}

Emmanuelle Labeau

School of Languages and Social Sciences

Aston University

Aston Triangle

BIRMINGHAM B4 7ET

United Kingdom

e.labeau@aston.ac.uk 